\title{
Amyloidogenic Processing of the Human Amyloid Precursor Protein in Primary Cultures of Rat Hippocampal Neurons
}

\author{
Mikael Simons, 1,2 Bart De Strooper, ${ }^{2,3}$ Gerd Multhaup,, Pentti J. Tienari,, ${ }^{1,2}$ Carlos G. Dotti, ${ }^{2}$ \\ and Konrad Beyreuther ${ }^{1}$
}

${ }^{1}$ Center for Molecular Biology Heidelberg, University of Heidelberg, D-69120 Heidelberg, Germany, ${ }^{2}$ Cell Biology Program, European Molecular Biology Laboratory, D-69012 Heidelberg, Germany, and ${ }^{3}$ Center for Human Genetics, 3000 Leuven, Belgium

The aim of this study was to investigate the proteolytic processing of the amyloid precursor protein (APP) in polarized primary cultures of hippocampal neurons. We have used the Semliki Forest virus (SFV) vector to express human APP695 in hippocampal neurons, sympathetic ganglia, and glial cells. The latter two cells secrete little or no APP, whereas hippocampal neurons secrete two forms of APP695, which differ in sialic acid content and in their kinetic appearance in the culture medium. In addition, rat hippocampal neurons expressing human APP produced significant amounts of the $4 \mathrm{kDa}$ peptide $\beta \mathrm{A} 4$. After 3 hr of metabolic labeling, the relative amount of $\beta A 4$ peptide to total cellular APP was 5.3\%. Fibroblasts expressing APP695 using the same SFV vector mainly produced a related $3 \mathrm{kDa}$ p3 peptide, a nonamyloidogenic fragment. Remarkably, the hippocampal neurons also produced significant amounts of $\beta A 4-$ containing C-terminal fragments (10-12 kDa) intracellularly. Radiosequencing showed that these fragments were created at a previously described $\beta$-secretase cleavage site and at a cleavage site 12 residues from the $N$ terminus of the $\beta A 4$ domain (Thr ${ }^{584}$ of APP695), which we named $\delta$-cleavage. Based on the observation that mature hippocampal neurons produce two potentially amyloidogenic fragments and secrete substantial amounts of $\beta A 4$ when expressing human APP, our results strengthen the hypothesis that neurons play a central role in the process of $\beta A 4$ deposition in cases of Alzheimer's disease and in aged primates.

Key words: Alzheimer's disease; hippocampal neurons; SFV vector; amyloid precursor protein; $\beta$-amyloid peptide; amyloidogenic processing
The amyloid precursor protein (APP) is a widely expressed $100-140 \mathrm{kDa}$ integral membrane protein with a large N-terminal ectodomain and a small C-terminal cytoplasmic domain (Kang et al., 1987). Although its physiological function remains unknown, several findings suggest a central role for APP in the pathogenesis of Alzheimer's disease (AD) (Selkoe et al., 1994). APP is the parent molecule for a small, 39-43 residue amyloid peptide ( $\beta A 4)$, which is the principal component of the senile plaques and vascular amyloid found in the brains of AD patients (Glenner and Wong, 1984; Masters et al., 1985). Furthermore, families with hereditary forms of $A D$, or familial $\mathrm{AD}(\mathrm{FAD})$, carrying missense mutations in the APP gene have been identified (Mullan and Crawford, 1993), and overexpression of such human APP mutants in transgenic mice causes amyloid deposition and plaque formation of similar tinctorial properties such as those occurring in AD (Games et al., 1995). Although APP is expressed ubiquitously, pathological manifestations of $\mathrm{AD}$ such as $\beta \mathrm{A} 4$ deposits are found

\footnotetext{
Received June 21, 1995; revised Oct. 18, 1995; accepted Oct. 24, 1995.

This research was supported by SFB 317 (K.B., C.G.D.) and SFB 258 the Metropolitan Life Foundation, the Fonds der Chemischen Industrie, and the Forschungsschwerpunkt Baden-Wuertemberg (K.B.). B.D.S. is a postdoctoral fellow of the National Fonds for Scientific Research (NFWO, Belgium) and was supported by a short-term fellowship of EMBO. We thank Liane Meyn for the neuronal cultures. We are very grateful to the many investigators who provided probes and materials: B. Greenberg, T. Hartmann, A. Hemar, F. van Leuven, D. Selkoe, N. Robakis, H. Virta, and H. Wiesniewski. We thank H. Garoff and M.-L. Strand for help and advice in optimizing the recombinant SFV stocks.

Correspondence should be addressed to Dr. Konrad Beyreuther, Center for Molecular Biology Heidelberg (ZMBH), University of Heidelberg, Im Neuenheimer Feld 282, D-69120 Heidelberg, Germany.

Copyright 1996 Society for Neuroscience $0270-6474 / 96 / 160899-10 \$ 05.00 / 0$
}

exclusively in brain tissue, which suggests that there are mechanisms specific to the brain that are responsible for the pathogenesis. Among brain cells, neurons are strongly affected during $\mathrm{AD}$ by changes in their cytoarchitecture, giving rise to dystrophic neurites and neurofibrillary tangles. Neurons have been proposed as a potential source of $\beta A 4$ in the amyloid plaques based on indirect evidence showing that neurons accumulate APP in the neurites surrounding the amyloid deposits (Cork et al., 1990; Cras et al., 1991). Moreover, $\beta A 4$ depositions in the brain appear to spread along neuronal projections, supporting the idea that neurons play a causal role in the pathogenesis (Hyman et al., 1990).

Despite the great interest in neuronal APP processing in AD research, APP processing has been studied almost exclusively in non-neuronal cells. These studies have demonstrated that APP has thrce protcolytic clcavagc sites. After transport from the Golgi apparatus, APP can be cleaved within the $\beta A 4$ region ( $\alpha$-cleavage) (Esch et al., 1990; Sisodia et al., 1990), leading to the release of the large, $100 \mathrm{kDa}$ ectodomain that is secreted. The amount of secreted protein varies from cell to cell but does not appear to exceed $30 \%$ of totally synthesized protein (Weidemann et al., 1989; Caporaso et al., 1992; Selkoe et al., 1994). The molecules escaping $\alpha$-cleavage can be internalized from the cell surface, mediated via endocytosis signals in the cytoplasmic tails (Haass et al., 1992a,b; Koo and Squazzo, 1994), and then processed by $\beta$-cleavage at $\mathrm{Met}^{596}$ (numbering after APP695), creating the $\mathrm{N}$ terminus of $\beta \mathrm{A} 4\left(\mathrm{Asp}^{597}\right.$ ). This scission is followed by an additional cleavage ( $\gamma$-cleavage) in the region of $\mathrm{Val}^{636}$ to $\mathrm{Thr}^{640}$, releasing $\beta$ A4. APP processing is complicated further in cells that 
possess a polarized cell surface. In epithelial Madin-Darby canine kidney (MDCK) cells, APP is transported to the basolateral domain from which its proteolytic fragments, the $100 \mathrm{kDa}$ ectodomain and the $4 \mathrm{kDa} \beta A 4$ peptides, are sccreted (Haass et al., 1994; Lo et al., 1994; De Strooper et al., 1995a).

Neurons have a polarized cell surface like epithelia and are differentiated into somatodendritic and axonal territories (Craig and Banker, 1994). Little is known about APP processing in polarized neurons; therefore, we decided to study the metabolism of human APP695 in the hippocampal neuron culture system. During culture in vitro, the hippocampal neurons undergo a sequence of differentiation steps that leads to maturation into fully polarized cells with axons and dendrites forming synaptic networks on the culture dish (Dotti et al., 1988). These neurons share many biological properties with their counterparts in the brain and, therefore, constitute an excellent in vitro model. It has been shown that human APP695 is expressed in these neurons and that it is delivered first to the axons and then transported to dendrites by a mechanism similar to what has been termed "transcytosis" in epithelial cells (Simons et al., 1995). Similar results have been obtained with cndogenous APP in neuron culture, confirming that the overexpression of APP via the virus vector mimics the normally observed situation (Yamazaki et al., 1995).

To obtain sufficient levels of APP expression for biochemical analyses, we used recombinant Semliki Forest virus (SFV) coding for human APP695 to infect primary cultures of rat hippocampal neurons. This system has been used successfully to express heterologous proteins in neurons and offers the advantage of high protein expression without affecting the polarized organization of the cells during the early phase of infection (Ikonen et al., 1993; Olkkonen et al., 1993; De Hoop et al., 1994; Simons et al., 1995; De Strooper et al., 1995b).

\section{MATERIALS AND METHODS}

Cell culture. Hippocampal neuron cultures were prepared from 18-d-old fetal rats as described by Goslin and Banker (1991). Briefly, after the hippocampi were dissected and dissociated, the cells were plated on either poly-D-lysine-coated plastic dishes (at a density of $4 \times 10^{5}$ cells $/ 6$ $\mathrm{cm}$ dish) or glass coverslips (at a density of $1.5 \times 10^{5} \mathrm{cells} / 6 \mathrm{~cm}$ dish) and kept in minimum essential medium (MEM) supplemented with $10 \%$ horse serum. Cells were maintained in $5.0 \% \mathrm{CO}_{2}$ at $36.5^{\circ} \mathrm{C}$ in MEM with N2 supplement ("maintenance medium") (Bottenstein and Sato, 1979). Proliferation of non-neuronal cells was prevented by adding $5 \mu \mathrm{M}$ cytosine arabinoside.

Glial cultures were prepared as described by Goslin and Banker (1991). The cerebral hemispheres were removed from newborn rats and mechanically and chemically (trypsin) homogenized. Cells were cultured in MEM supplemented with $10 \%$ horse serum. To prevent neuronal contamination, only glial cultures that were passaged two to three times were used.

Superior cervical ganglia were dissected from 19- or 20-d-old fetal rats and prepared as described by Peng et al. (1986). Explants were cultured for $14 \mathrm{~d}$ in N2-MEM supplemented with $10 \mu \mathrm{M}$ fluorodeoxyuridine, 10 $\mu \mathrm{M}$ uridine, $20 \mu \mathrm{g} / \mathrm{ml}$ tri-iodo-L-threonine, and $10 \mathrm{ng} / \mathrm{ml} 2.5 \mathrm{~S}$ nerve growth factor before use.

Baby hamster kidney cells (BHK; CLL10) were cultured in Glasgow's modified Eagle's medium supplemented with $5 \%$ fetal calf serum (FCS), $2 \mathrm{mM}$ L-glutamine, $10 \%$ tryptose phosphate broth, $100 \mathrm{U} / \mathrm{ml}$ penicillin, and $100 \mathrm{gm} / \mathrm{ml}$ streptomycin.

Primary fibroblasts from 13.5-d-old mouse embryos were isolated as described previously (Robertson, 1987) and maintained in DMEM supplemented with $10 \%$ FCS, $2 \mathrm{~mm}$ glutamine, and antibiotics.

Antibodies. Antibodies (Abs) used in the experiments included polyclonal anti-FdAPP raised against purified Escherichia coli FdAPP fusion protein consisting of the following: APP695 and the Fd fragment of murine IgM heavy chain (Weidemann et al., 1989); 22C11, a monoclonal $\mathrm{Ab}(\mathrm{mAb})$ that recognizes a region between amino acids 66 and 81 of APP695 (Hilbich et al., 1993); Ab 692, a polyclonal Ab raised against human $\beta \mathrm{A} 4$ synthetic peptide $1-40 ; \mathrm{B} 12 / 4$, a polyclonal $\mathrm{Ab}$ against the 20
C-terminal amino acids of APP (De Strooper et al., 1995a); B7/6, a polyclonal $\mathrm{Ab}$ raised against synthetic human 1-40 $\beta \mathrm{A} 4$ peptide, which only recognizes the human 1-16 sequence (B. De Strooper, unpublished observations); R 217, made against APPs (Lowery et al., 1991); R1282, raised against human synthetic $1-40 \beta A 4$ peptide (Haass et al., 1992a,b); $\mathrm{R} 48$, raised against human synthetic $\beta A 4,1-16$ (Anderson et al., 1992); and $4 \mathrm{G} 8$, an mAb against residues $17-24$ of $\beta A 4$ (Kim et al., 1988). For immunoprecipitation, each $\mathrm{Ab}$ was used at 1:100 dilution except R217, which was used at 1:500, and B12/4, which was used at 1:1000. Ab 22C11 was used at 1:10,000 for immunoblotting.

DNA constructs. From the plasmid PreA4-pSP65 (Dyrks et al., 1988) containing the APP695 sequence, the SpeI site in the noncoding region of APP695 was removed by using the Klenow fragment. The $3 \mathrm{~kb} S \mathrm{Smal}$ fragment containing the complete coding region of the APP695 cDNA was subcloned into the Smal site of pSFV 1 (Liljestrom and Garoff, 1991).

Preparation of recombinant SFV. The pSFV-APP695 (human) and the pSFV-helper 1 were linearized with SpeI, and runoff transcription was performed with SP6 RNA polymerase. Each APP transcription mix was cotransfected with the helper-transcription mix to BHK cells using electroporation as described by Olkkonen et al. (1993). The culture supernatant was collected after $20-24 \mathrm{hr}$ incubation $\left(5 \% \mathrm{CO}_{2}, 37^{\circ} \mathrm{C}\right)$. The virus-containing supernatant was titrated on BHK cells as described by Olkkonen et al. (1993).

Infection of the netrons and metabolic labeling. Recombinant SFV diluted in conditioned maintenance medium was placed on 7- to 14-d-old neurons. After allowing viral entry for $1 \mathrm{hr}\left(5 \% \mathrm{CO}_{2}, 37^{\circ} \mathrm{C}\right)$, the virus solution was replaced by maintenance medium and the infection continued for 2-3 hr. The medium then was exchanged by methionine-free MEM with $1 / 10 \mathrm{~N} 2$ supplement containing $15 \mathrm{mg} / 1$ methionine and $1 \%$ egg albumin. Metabolic labeling was performed for $3 \mathrm{hr}$ with $200 \mu \mathrm{Ci} / \mathrm{ml}$ $\left[{ }^{35} \mathrm{~S}\right]$ methionine. In time-course experiments $3 \mathrm{hr}$ after infection, cells were pulsed for $10 \mathrm{~min}$ with methionine-free MEM containing 300 $\mu \mathrm{Ci} / \mathrm{ml}\left[{ }^{35} \mathrm{~S}\right]$ methionine. Next, cells were washed twice with maintenance medium, and fresh medium was added at $0,30,60$, and $120 \mathrm{~min}$ after radioactive pulse. Culture medium from each time interval was processed immediately for immunoprecipitation. For in vivo labeling with [ $\left.{ }^{32} \mathrm{P}\right]$ orthophosphate, neurons were incubated $3 \mathrm{hr}$ after infection in phosphate-free MEM supplemented with $1 / 10 \mathrm{~N} 2$ supplement containing $158 \mathrm{mg} / 1 \mathrm{NaH}_{2} \mathrm{PO}_{4}$ for $15 \mathrm{~min}$ and then labeled with $1 \mathrm{mCi} / \mathrm{ml} \mathrm{H}_{3}{ }^{32} \mathrm{PO}_{4}$ for $3 \mathrm{hr}$. Extracellular medium was processed as described, exeept that orthovanadate $(100 \mu \mathrm{M})$ and sodium fluoride $(50 \mathrm{~mm})$ were added.

Immunoprecipitation, immunoblotting, gel electrophoresis, and quantification. After metabolic labeling, culture medium was harvested and cell extracts were prepared in $1 \%$ Triton $\mathrm{X}-100,1 \%$ sodium deoxycholate, and $0.1 \%$ SDS with $10 \mu \mathrm{g} / \mathrm{ml}$ chymostatin, leupeptin, anti-papain, and pepstatin. Both culture medium and cell extracts were cleared first from precipitations, cell debris, and nuclei via $15 \mathrm{~min}$ centrifugation. The supernatant was incubated with $\mathrm{Ab}$ overnight at $4^{\circ} \mathrm{C}$. Immune complexes were recovered with protein A-Sepharose or protein G-agarose and processed as described previously (De Strooper et al., 1993). In the case of mAbs, polyclonal rabbit anti-mouse was used as capture $A b$. For immunoblotting, cell extracts and extracellular medium were precipitated in $10 \%$ trichloroacetic acid (TCA), washed with acetone, and solubilized in SDS sample buffer. TCA precipitates and immunoprecipitated proteins were separated by $6 \%$ Tris-glycine, $4-20 \%$ Tris-glycine, or $10-20 \%$ Tris-tricinc polyacrylamide gels (Novex, San Diego, CA). We used lowrange See Blue prestained standard (Novex) and high-range prestained SDS-PAGE standard (Bio-Rad, Richmond, CA) as molecular weight standards. Gels were enhanced by Intensify (DuPont NEN, Boston, MA), dried, and exposed to Kodak XAR film (Rochester, NY). For immunoblotting, membranes were blocked in PBS $/ 5 \%$ milk and $0.2 \%$ Triton $\mathrm{X}-100$ and incubated for $1 \mathrm{hr}$ at room temperature with primary $\mathrm{Ab}$ diluted in blocking buffer. Appropriate horseradish peroxidase-labeled secondary $\mathrm{Ab}$ (Bio-Rad) was added for $30 \mathrm{~min}$. Blots were developed by enhanced chemiluminescence (Amersham Buchler, Braunschweig, Germany). The intensity of radiolabeled bands was calculated using densitometric scanning (Molecular Dynamics, Sunnyvale, CA).

Enzymatic deglycosylation. For digestion with neuraminidase (Boehringer Mannheim, Indianapolis, IN), immunoprecipitates were made with $1 \%$ SDS and $1 \% \beta$-mercaptoethanol, boiled for $5 \mathrm{~min}$, and diluted 10 -fold to final concentrations of $50 \mathrm{~mm}$ sodium acetate and $4 \mathrm{~mm}$ calcium chloride, pH 5.5, $1 \%$ Nonidel P-40, 0.1\% SDS, $10 \mu \mathrm{g} / \mathrm{ml}$ chymustatin, leupeptin, anti-papain, pepstatin, and $10 \mathrm{mU} / \mathrm{ml}$ neuraminidase. After incubation at $37^{\circ} \mathrm{C}$ for $16 \mathrm{hr}$, samples were analyzed by SDS-PAGE. 
Samples treated with $N$-glycosidase F (10 U/ml, Boehringer Mannheim) were buffered in $50 \mathrm{~mm}$ sodium phosphate buffer, $\mathrm{pH} \quad 7$. For $O$-glycosidase (Boehringer Mannheim) treatment, immunoprecipitates were preincubated with $1 \mathrm{mU}$ of neuraminidase at $37^{\circ} \mathrm{C}$ for $3 \mathrm{hr} ; 3 \mathrm{mU}$ of $\mathrm{O}$-glycosidase was used in sodium phosphate buffer, $\mathrm{pH}$ 7. As a control for unspecific degradation, parallel samples were incubated in the absence of enzymes.

Radiosequencing. After SDS-PAGE, $\left[{ }^{35}\right.$ S $]$ methionine- and $\left[{ }^{3} \mathrm{H}\right]$ phenylalaninelabeled proteins were blotted into ProBlott membranes (Applied Biosystems, Foster City, CA). Membranes were subjected first to autoradiography, and strips were excised corresponding to the bands visualized by autoradiography. A modified cycle was used for protein sequencing on the Model 477A Protein Sequencer (Applied Biosystems). In the solventwash step, the S1 (n-heptane) delivery time was reduced from 100 to 25 sec. The S2 (ethyl acetate) delivery time was reduced to a total of $105 \mathrm{sec}$ divided into three $35 \mathrm{sec}$ deliveries alternated with two $5 \mathrm{sec}$ pause steps. In the anilinothiazolinone extraction step, the S3 transfer step (52 sec) was split into three $25 \mathrm{sec}$ transfers. Each transfer was followed by a $5 \mathrm{sec}$ pause step and a $5 \mathrm{sec}$ transfer with argon. The solvent was directed entirely to the fraction collector, and each fraction was mixed with $3.5 \mathrm{ml}$ of liquid scintillator (Ready Protein Cocktail, Beckman, Fullerton, CA) before counting for $10 \mathrm{~min}$ (Beckman LS 6000IC).

Immunofluorescence. Immunofluorescence was performed as described previously (Simons et al., 1995). Cells were fixed with $4 \%$-formaldehyde in PBS, pH 7.4, quenched with $50 \mathrm{mM} \mathrm{NH}_{4} \mathrm{Cl}$ in PBS for 20 min, permeabilized with increasing concentrations of ethanol, and blocked in $2 \%$ bovine serum albumin, $2 \% \mathrm{FCS}$, and $0.2 \%$ gelatin in PBS. The cells were incubated in the presence of primary Ab (anti-FdAPP and anti-MAP2) and fluoroscein- or rhodamine isothiocyanate-conjugated secondary Abs, as described by Simons et al. (1995). The coverslips were mounted in Moviol (Hoechst, Frankfurt, Germany), and the cells were viewed using an Axiophot (Zeiss, Jena, Germany). Photographs were taken using high-sensitivity film (Tmax 3200 , Kodak)

\section{RESULTS}

To analyze processing and secretion of endogenous APP, neuronal cultures were labeled in the presence of $\left[{ }^{35} \mathrm{~S}\right]$ methionine for 3 $\mathrm{hr}$, and cell lysate and extracellular medium were subjected to immunoprecipitation by a panel of different Abs against C- and N-terminal epitopes of APP (see Materials and Methods). The Abs revealed a prominent band at $115 \mathrm{kDa}$ in the cell homogenate and a doublet of 120 and $100 \mathrm{kDa}$ in the culture medium (Fig. 1A). A C-terminal Ab recognized the $115 \mathrm{kDa}$ band from the cell lysate but not the APP cleavage products in the culture medium (data not shown), indicating that the latter forms had lost their cytoplasmic tails. The possibility that one of the bands in the culture medium represents the APP-like protein (APLP 1 or 2) was ruled out because both bands reacted with Ab R48 against epitope 1-16 of $\beta A 4$ (not present in APLP) in immunoblots (Fig. $2 A$ ) and immunoprecipitations (data not shown).

To analyze the processing and secretion of APP in more detail, we used the SFV-based protein expression system (Liljestrom and Garoff, 1991). Neuronal cultures were infected by recombinant SFV carrying human APP695 and metabolically labeled with $\left[{ }^{35} \mathrm{~S}\right]$ methionine for $3 \mathrm{hr}$. Expression of human APP695 in hippocampal neurons led to secretion of the same 100 and $120 \mathrm{kDa}$ bands (Fig. 1A), demonstrating that the use of this vector system led to processing similar to that observed for the endogenous APP. Also, the fact that the distribution of the endogenous marker protein MAP2 remained polarized during virus infection supports the use of this expression system for a detailed analysis of APP processing (Fig. 3B).

Primary neuronal cultures always contain a low amount of glial cells (5-20\%). To investigate the possible contribution of infected glial cells to the APP produced by the neurons, a subconfluent homogenous culture of glial cells was infected and processed in parallel, and levels of APP expression were compared in both the hippocampal and the glial cultures. In addition, an explant of
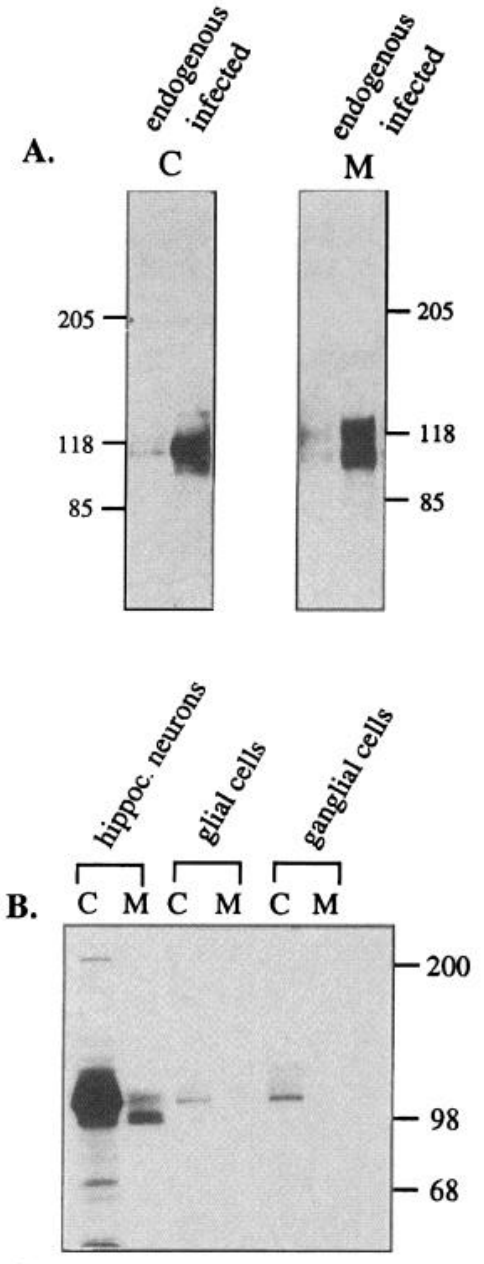

C.

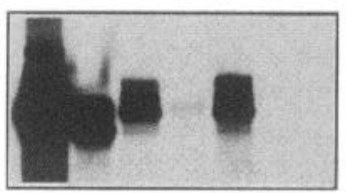

(overexposed fig. B.)

Figure 1. Immunoprecipitation of $\left[{ }^{35} \mathrm{~S}\right]$ methionine-labeled APP from cell homogenate and extracellular medium. A, Endogenous APP- and SFVexpressed APP695 (infected) were immunoprecipitated with Ab R217 from cell homogenate $(C)$ and extracellular medium $(M)$ of mature primary hippocampal neuron cultures after a $3 \mathrm{hr}$ metabolic labeling with $\left[{ }^{35} \mathrm{~S}\right]$ methionine. Note the comigration of endogenous and SFV-expressed APP695. B, A hippocampal neuron (hippoc. neurons) culture $\left(4 \times 10^{5}\right.$ cells) and a glial culture $\left(10^{6}\right.$ cells) (glial cells) were infected with SFVcarrying APP695 and labeled for $3 \mathrm{hr}$ with $\left[{ }^{35} \mathrm{~S}\right]$ methionine. Immunoprecipitations of cell homogenate $(C)$ and extracellular medium $(M)$ were performed with Ab R217. Glial cells show little APP expression compared with hippocampal neuron cultures. Six cervical ganglion explants (ganglial cells) were infected with SFV-containing APP695 and metabolically labeled for $8 \mathrm{hr}$. Resulting cell homogenate $(C)$ and conditioned medium $(M)$ were pooled and processed as above. $C$, Overexposed version of $B$. Fluorogram was exposed for 3 weeks. Note the reduced secretion of glial cell cultures compared with neuronal cultures in $B$ and the absence of detectable secretory APP in culture media of cervical ganglions.

superior cervical ganglia, as a source for peripheral neurons, also was investigated for secretion (Fig. $1 B, C$ ). It is clear from Figure $1 B$ that glial cells were infected much less efficiently with recombinant SFV than were the hippocampal neurons under the exper- 

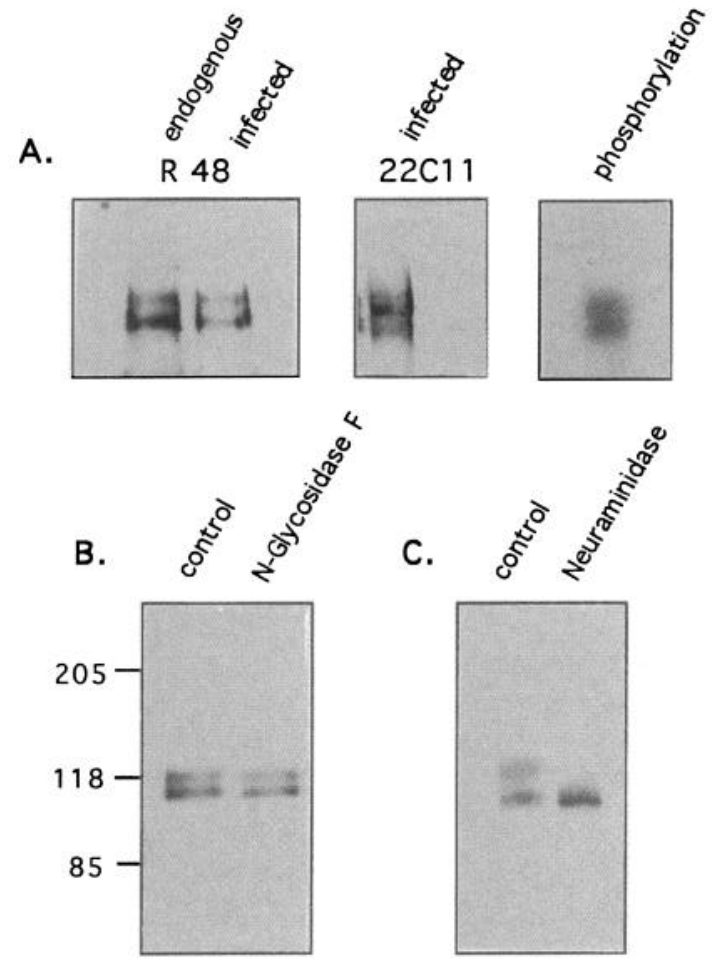

Figure 2. Characterization of secreted APP695. A: Left, Immunoblotting of endogenous secreted APP (endogenous) and SFV-expressed APP695 (infected) with Ab R48 specific for $\beta \mathrm{A} 4$ 1-16 from conditioned media of cultured hippocampal neurons ( $R 48 ; 10$-fold more medium was used from noninfected neuronal cultures). Middle, Immunoblotting of culture medium from SFV/APP695 neurons infected with Ab 22C11. Right, Immunoprecipitation of cultured media from infected SFV/695 and $\left[{ }^{32} \mathrm{P}\right]$ phosphate-labeled neurons (phosphorylation) with Ab R217. $B, C$, Endoglycosidase $\mathrm{F}$ and $\mathrm{C}(\mathrm{N}$-Glycosidase $\mathrm{F})$ and neuraminidase treatment of immunoprecipitated SFV-expressed secretory APP695 from culture medium of hippocampal neurons. In $B$ and $C$, the left lanes contain control samples that were incubated in the absence of enzyme.

imental conditions. Interestingly, glial cells secreted only minor amounts of APPs, detectable only after overexposure of the gels (Fig. 1C), which confirms previous investigations (Haass et al., 1991). Because the glial cultures contained at least 10 -fold more glial cells than the hippocampal cultures routinely used, we concluded that contaminating glial cells did not contribute significantly to the pool of APP observed in our experiments. Although these experiments clearly demonstrate secretory processing of APP by hippocampal neurons, significant secretory processing of APP in the ganglion explant was not observed, even though the cells were infected by the virus and expressed APP695 (Fig. 1B,C).

To determine the time course of APP secretion, one dish $(4 \times$ $10^{5}$ cells) of infected hippocampal neurons was pulse-labeled for $10 \mathrm{~min}$, and medium was assayed for secreted APP after 30, 60, 120, and $180 \mathrm{~min}$ of chase (Fig. 4). At each time point, the complete medium was collected and replaced with an equal amount of fresh medium. Figure 4 represents the fractional accumulation of the pulse-labeled APP into the culture medium. Secretion of APP in hippocampal neurons was slow, and even after $3 \mathrm{hr}$ APP from the pool synthesized during the $10 \mathrm{~min}$ pulse labeling continued to appear in the culture medium. Moreover, the overall kinetics of this process was not only somewhat different from that of other cells (Weidemann et al., 1989; Oltersdorf et al., 1990), but intriguing kinetic differences in the appearance of the two secretory APP products also were observed. The $120 \mathrm{kDa}$ form appeared first, and its secretion was almost complete 120 min after the pulse, whereas the $100 \mathrm{kDa}$ form was observed only after $60 \mathrm{~min}$ and was still being secreted after $180 \mathrm{~min}$ of chase. This was confirmed in four independent experiments with two different Abs. Quantitation of the kinetic differences is shown in Figure $4 B$.

Because in other cells APP695 usually yields one single secreted APP with $M_{\mathrm{r}} \sim 100 \mathrm{kDa}$ (Weidemann et al., 1989; Esch et al., 1990; Oltersdorf et al., 1990; Golde et al., 1992), the nature of two soluble APPs in hippocampal cultures was explored further. Proteolysis of the higher molecular weight form by proteases present in the extracellular medium was excluded, because incubation of culture supernatant at $37^{\circ} \mathrm{C}$ during $3 \mathrm{hr}$ in the absence of proteinase inhibitors did not change the ratio between the two forms (data not shown). Furthermore, both proteins reacted in immunoblots with Abs that recognize the $\mathrm{C}$ - and $\mathrm{N}$-terminal ends of secretory APP (Fig. 2A), confirming that proteolysis in the culture medium was not involved in the generation of the two bands. Therefore, other post-translational modifications were investigated. Both proteins were weakly phosphorylated to a similar level (Fig. $2 A$ ), excluding the possibility that one band is phosphorylated and the other is not. Glycosylation was explored using carbohydrate-cleaving enzymes. Endoglycosidase F decreased the molecular weight of both bands by $\sim 2 \mathrm{kDa}$, indicating similar levels of N-glycosylation (Fig. $2 B$ ). Treatment with neuraminidase caused the disappearance of the upper band and comigration of the upper band with the lower band (Fig. $2 C$ ). Treatment with $O$-glycosidase and neuraminidase led to the same result (data not shown). These results demonstrate that the heterogeneity of secreted APP695 in hippocampal neurons is caused by a higher content of sialic acids in the upper band, causing an increased $M_{\mathrm{r}}$ ( $\sim 20 \mathrm{kDa})$.

One of the issues in $\mathrm{AD}$ that is still unresolved is to what extent neurons are able to produce $\beta \mathrm{A} 4$ and other low molecular weight peptides, including $\mathrm{p} 3$. The $\mathrm{p} 3$ peptide arises from cleavage by $\alpha$-secretase within the $\beta \mathrm{A} 4$ domain and comprises $\beta \mathrm{A} 4$ residues 17-40.

One dish containing $\sim 4 \times 10^{5}$ hippocampal neurons was infected with recombinant SFV/APP695 and labeled for $3 \mathrm{hr}$ with $200 \mu \mathrm{Ci} / \mathrm{ml}\left[{ }^{35} \mathrm{~S}\right]$ methionine to analyze whether $\beta \mathrm{A} 4$ was secreted. Immunoprecipitation was carried out on the culture medium with the well characterized antiserum R1280 (Haass et al., 1992b), which precipitates both $\beta \mathrm{A} 4$ and $\mathrm{p} 3$ fragments in other cell cultures. A major $4 \mathrm{kDa}$ protein was observed after $24 \mathrm{hr}$ exposure of the gel (Fig. $5 A$ ), whereas a very weak p3 signal was observed only after longer exposures (data not shown). For comparison, we expressed APP695 in primary mouse fibroblasts via the SFV vector (Fig. $5 B$ ). The ratio of $\beta A 4$ to $\mathrm{p} 3$ was reversed, demonstrating that hippocampal neurons differ in their processing of APP695. The $4 \mathrm{kDa}$ peptide secreted from the neurons was identified as authentic $\beta A 4$ peptide because it reacted with both mAb 4G8 against amino acids $17-24$ and polyclonal Ab B7/6, which is specific for amino acids $1-16$ of the $\beta A 4$ sequence (Fig. $5 A$ ). Radiosequencing of the protein confirmed that the peptide was indeed $\beta \mathrm{A} 4$, starting at $\mathrm{Asp}^{1}$ of the $\beta$-amyloid sequence (Fig. $5 C$ ). Densitometric scanning analysis showed that the relative amount of secreted $\beta \mathrm{A} 4$ peptide to total cellular APP (corrected for methionine content) was already $5.3 \pm 1.9 \%(n=6)$ after $3 \mathrm{hr}$ of labeling.

Finally, we investigated the C-terminal APP fragments produced by hippocampal neurons. After infection and metabolic labeling, the 

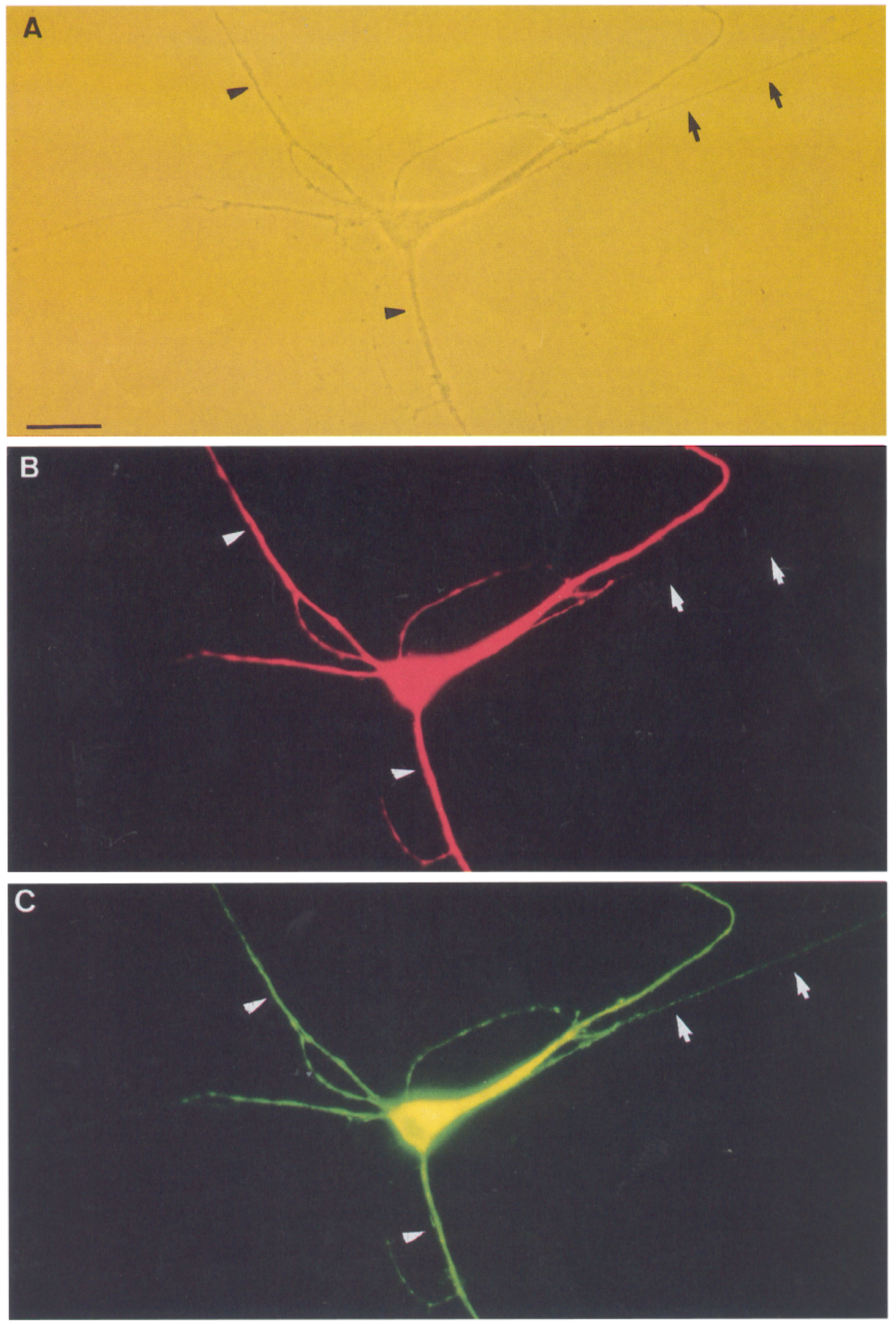

Figure 3. Expression of APP695 via the SFV vector does not change the polarity of the endogenous marker MAP2. A hippocampal neuron infected with recombinant SFV is shown $6 \mathrm{hr}$ after infection in phase-contrast $(A)$, with MAP2 labeling $(B)$, and with APP 695 labeling $(C)$. Note the absence of axonal MAP2, whereas the axon is labeled with anti-APP. The axon is marked with arrows, and the dendrites are marked with arrowheads. 

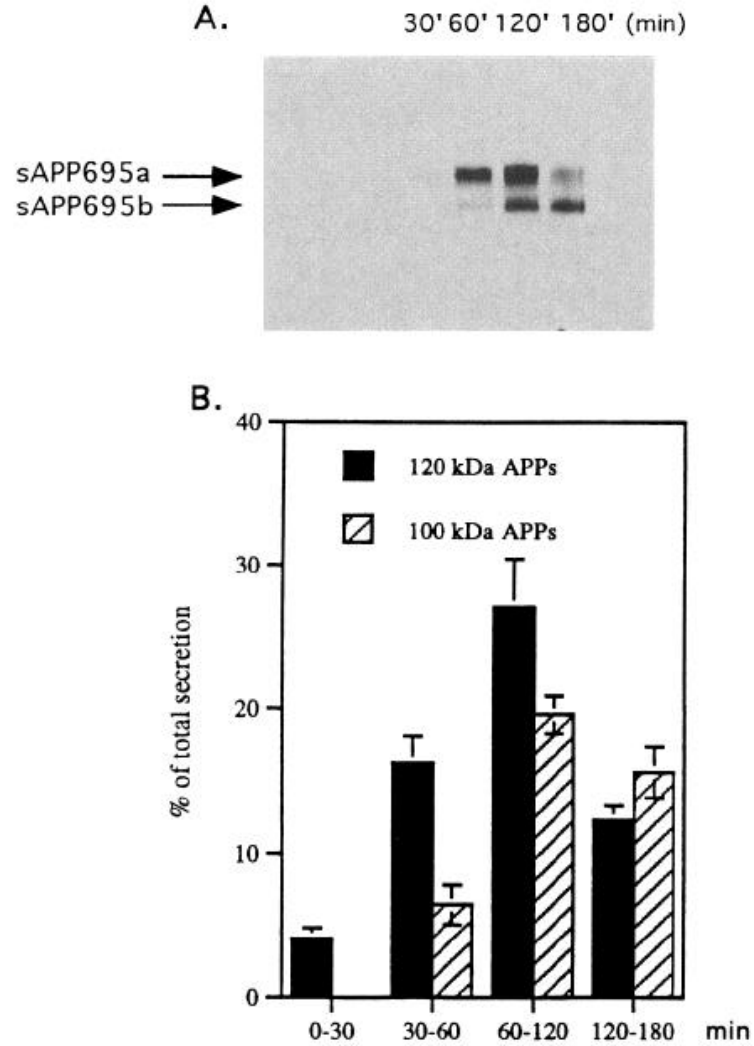

Figure 4. Time course of APP695 secretion in hippocampal neuron cultures. A, SFV/APP695-infected hippocampal neurons were pulselabeled for $10 \mathrm{~min}$ with $\left[{ }^{35} \mathrm{~S}\right]$ methionine, and culture media were collected at the times indicated (see also Materials and Methods). Secreted APP695 was immunoprecipitated with Ab R217 at each time interval. $B$, Quantitative analysis of four independent experiments performed as in A. Filled columns indicate $120 \mathrm{kDa}$ APPs; hashed columns indicate $100 \mathrm{kDa}$ APPs.

cell lysates were immunoprecipitated with Ab B12/4 against the 20 C-terminal amino acid residues of the cytoplasmic tail of APP. In $10-20 \%$ of the Tris-tricine polyacrylamide gels, four C-terminal fragments appeared between 8 and $12 \mathrm{kDa}$ (Fig. 6A). The two upper bands reacted with $\mathrm{Ab} \mathrm{B} 7 / 6$, indicating that they contained the entire $\beta A 4$ peptide (data not shown). By densitometric scanning analysis, the relative amount (corrected for methionine content) of the C-terminal fragments compared with that of full-length APP was shown to be $13.4 \pm 5.25 \%(n=8)$ after $3 \mathrm{hr}$ of labeling. The $\beta$ A4-containing (potentially) amyloidogenic fragments represented $\sim 67 \%$ of the C-terminal fragments.

The sequence of the $8,8.5,10$, and $12 \mathrm{kDa} C$-terminal derivatives was identified by radiosequencing. $\left[{ }^{35} \mathrm{~S}\right]$ Methionine or $\left[{ }^{3} \mathrm{H}\right]$ phenylalanine metabolically radiolabeled C-terminal fragments were isolated from $10-20 \%$ of the Tris-tricine gels and subjected to $\mathrm{N}$-terminal radiosequence analysis (Fig. 6B-D). The $12 \mathrm{kDa}\left[{ }^{35} \mathrm{~S}\right]$ methionine-labeled fragment revealed a radioactive signal at cycle 12. Alignment with the known sequence of APP indicated that cleavage of APP had occurred at the 12 amino acids $\mathrm{N}$-terminal to $\beta \mathrm{A} 4$ (Fig. $6 B$ ). The results show that neuronal cells are capable of generating a fourth cleavage at the $\mathrm{N}$-terminal side of the $\beta$-cleavage site, which we propose to name the $\delta$-cleavage site, which is generated in neurons by an unidentified $\delta$-secretase.

Radiosequencing of the $\left[{ }^{35} \mathrm{~S}\right]$ methionine-labeled $10 \mathrm{kDa}$ fragment caused ${ }^{35} \mathrm{~S}$ peaks in cycle 4 and cycles $19-20$, indicating that this band was generated by $\beta$-cleavage (Fig. $6 C$ ). The 8 and $8.5 \mathrm{kDa}$ fragments could not be separated from each other and, therefore, were radiosequenced as a mixture. $\left[{ }^{3} \mathrm{H}\right] \mathrm{Phenylalanine}$ radioactivity peaks were obtained at cycles $3,4,5,6,9$, and 10 (Fig. $6 D$ ). These results confirm that the fragments in these bands are heterogeneous, likely consisting of C-terminal fragments starting at Leu ${ }^{17}$ of the classical $\alpha$-secretase site and at two other positions, i.e., Glu ${ }^{11}$ and $\mathrm{Gln}^{15}$ of the $\beta \mathrm{A} 4$ sequence. For simplicity, we will call the two additional sites $\alpha^{\prime}$ secretase sites, although the site at position Gln ${ }^{11}$ likely is also amyloidogenic, because an important fraction of peptides in amyloid plaques of AD patients starts exactly at that position (Masters et al., 1985; Naslund et al., 1994).

\section{DISCUSSION}

Although the metabolism of APP has been studied in detail in many cell types, information about the processing of APP in the cells that are affected in AD, i.e., hippocampal neurons, is absent. The reason for this is the difficulty in obtaining sufficient amounts of material from cultured neurons for biochemical analyses. We circumvented this problem by expressing human APP695 via the SFV-expression system. This vector is ideally suited for this purpose because a wave of newly synthesized APP is transported through the biosynthetic pathway after infection; therefore, posttranslational modifications can be monitored easily. All of our controls in this study (Figs. 1, 3) and in previous studies (Simons et al., 1995; Yamazaki et al., 1995) suggest that the membranetrafficking systems in these neurons perform normally during the time course of the study.

Particularly important was the observation that rat hippocampal neurons are able to produce $\beta A 4$ peptide in relatively high amounts compared with the p3 peptide when expressing human APP695. We evaluated this by using the widely used Ab R1282. This $\mathrm{Ab}$ usually precipitates more $\mathrm{p} 3$ (residues $17-40$ of $\beta \mathrm{A} 4$ ) than $\beta \mathrm{A} 4$ from a variety of cells, including stably transfected human 293 kidney cells and MDCK cells, Chinese hamster ovary cells, and human umbilical vein endothelial cells (Haass et al., 1992b, 1994). In contrast, we found that rat hippocampal neurons produce substantial amounts of $\beta \mathrm{A} 4$, whereas $\mathrm{p} 3$ was visible only faintly, even after prolonged exposure of the fluorographs from R1282 immunoprecipitations. A reverse ratio was observed in fibroblasts (Fig. $5 B$ ). Because the small amounts of contaminating glial cells in the cultures did not contribute significantly to APP production after SFV infection (Fig. $1 B, C$ ), our conclusion is that the hippocampal neurons are the source of the $\beta \mathrm{A} 4$ peptide.

Previously, $\beta A 4$ production has been studied in a number of brain-derived cell types, including rat astrocytes, human astrocytes, rat cortical and hippocampal neuronal cultures, and human mixedbrain cultures (Haass et al., 1992b; Busciglio et al., 1993). These studies found that mostly $\mathrm{p} 3$ was produced from rodent neuronal cultures, whereas human astrocytes and human mixed-brain cultures produced the highest levels of $\beta A 4$. The discrepancy with our findings could be attributable to the difficulty in detecting significant amounts of $\beta \mathrm{A} 4$ in rodent neurons because of reduced affinity of the anti- $\beta A 4$ Abs to the rodent $\beta A 4$ peptide. Another possibility is that rodent neurons indeed produce only small amounts of endogenous $\beta A 4$. Only after human APP was introduced into these cells would they start secreting $\beta A 4$. Recent results from our laboratories demonstrate that rodent APP expressed via the SFV vector produces much smaller amounts of $\beta A 4$ compared with the amounts observed after expressing human APP. Several familial APP mutants, however, produced more $\beta A 4$ wild-type APP695 (De Strooper et al., 1995b). These data are in agreement with the results obtained with the recent transgenic mouse model expressing human APP with 

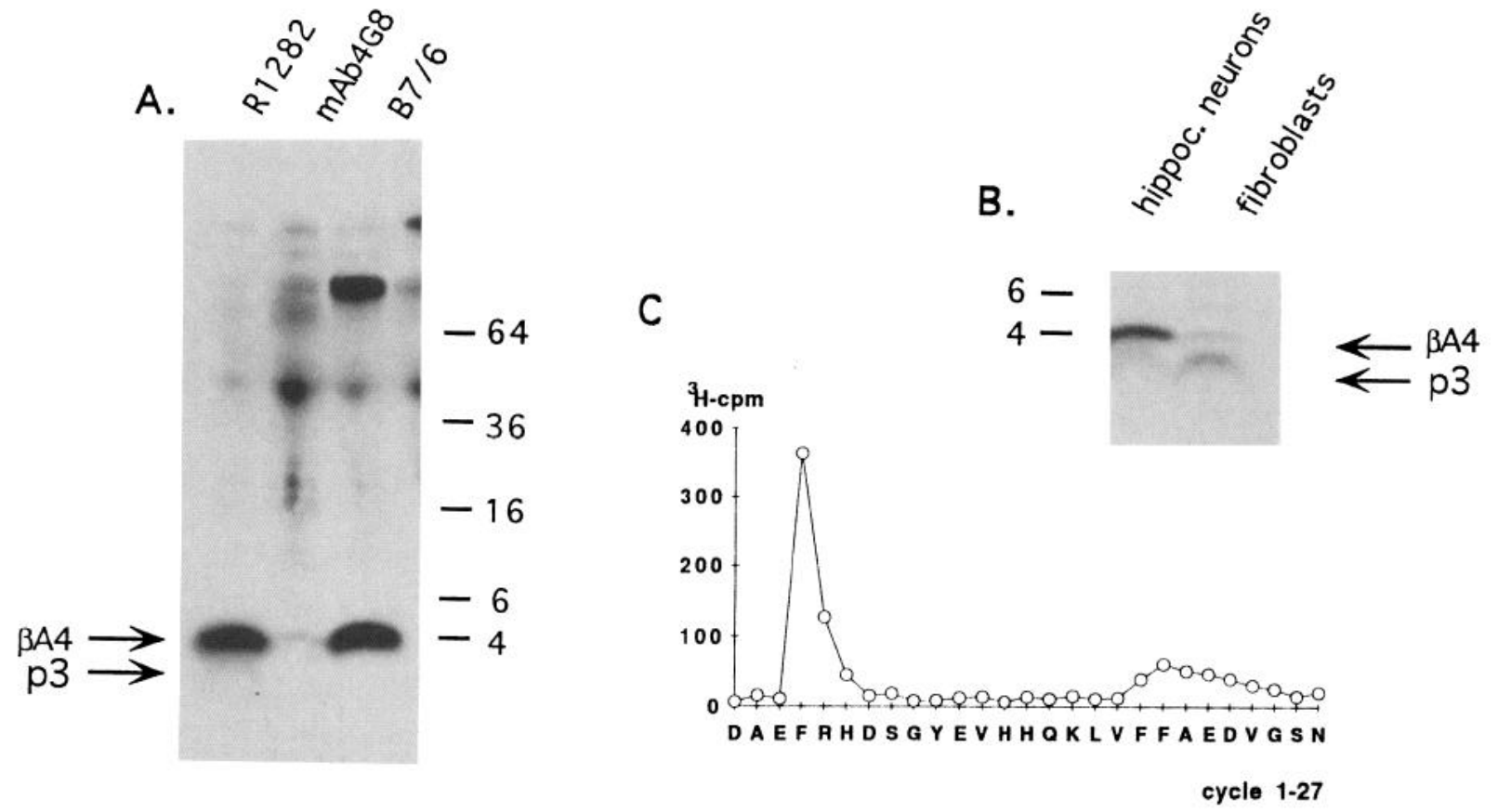

Figure 5. $\quad \beta A 4$ secretion from primary cultures of hippocampal neurons. $A$, Immunoprecipitation of $\beta$ A4 from culture medium of SFV/APP695-infected neurons after a $3 \mathrm{hr}\left[{ }^{35} \mathrm{~S}\right]$ methionine labeling with the polyclonal $\mathrm{Ab} R 1282$ (against $\beta \mathrm{A} 4$ 1-40), the monoclonal Ab 4G8 (mAb4G8) (against $\beta \mathrm{A} 4$ 17-24), and the polyclonal $\mathrm{Ab} B 7 / 6$ (against $\beta \mathrm{A} 41-16$ ). B. Comparison of $\beta \mathrm{A} 4 / \mathrm{p} 3$ ratio in hippocampal neurons (hippoc. neurons) and fibroblasts. APP695 was expressed via the SFV vector, and cells were labeled with $\left[{ }^{35} \mathrm{~S}\right]$ methionine for $3 \mathrm{hr}$. Medium was immunoprecipitated with Ab 692 . A high $\beta A 4 / \mathrm{p} 3$ was observed in hippocampal neurons. The ratio was reversed in fibroblasts. $C$, Radiosequencing of a $\left[{ }^{3} \mathrm{H}\right]$ phenylalanine-labeled $4 \mathrm{kDa}$ peptide from culture medium of hippocampal neurons.

FAD 717 (FAD mutant; mutation in codon 717), which produced typical AD-associated amyloid plaques (Games et al., 1995).

In contrast to previous studies, which concluded that secretory processing of APP in neurons was less prominent (Haass et al., 1991; Hung et al., 1992) or nonexistent (Alliquant et al., 1994), we found appreciable $\alpha$-secretase processing of APP695 in both uninfected and infected hippocampal neurons. In our opinion, the reasons for this apparent discrepancy between our findings and those of others most likely are to be found at the level of the neuronal culture systems that were used. The hippocampal neuron culture used here yields well differentiated neurons that elaborate many interneuronal contacts (Goslin and Banker, 1991). These interneuronal contacts may be important in this respect because we found that neurons derived from cervical sympathetic ganglion cells, which do not form synaptic contacts in vitro, did not secrete APP in detectable amounts (Fig. $1 B, C$ ). The alternative possibility that secretory processing of APP is a particular characteristic of hippocampal neurons [as opposed to cortical neurons used in the other study (Alliquant et al., 1994) and sympathetic neurons used here] cannot be ruled out at this time.

Secretory processing of APP in hippocampal neurons is somewhat slower than that of non-neuronal cells and, in contrast to other cells (Weidemann et al., 1989; Oltersdorf et al., 1990), it yielded two APP forms of $\sim 100$ and $120 \mathrm{kDa}$ in the extracellular medium. Both forms are phosphorylated and N-glycosylated, but they contain different amounts of sialyl residues because they both migrate together as a single band in SDS-PAGE after treatment with neuraminidase (Fig. $2 C$ ). Intriguingly, a short pulse (10 min) of metabolic labeling caused secretion of labeled APPs for $>3 \mathrm{hr}$. The sialic acid-rich form of $120 \mathrm{kDa}$ started to appear in the medium after $30-60 \mathrm{~min}$, whereas the $100 \mathrm{kDa}$ form appeared only after $60 \mathrm{~min}$ and beyond (Fig. 4). The most likely interpre- tation of these results is that the secretory processing of APP in neurons is a complex process taking place at different stations during APP trafficking in the neurons. We do not know whether the latter form is produced by desialylation of the $120 \mathrm{kDa}$ form, e.g., after endocytosis and subsequent release by recycling, or whether the $100 \mathrm{kDa}$ is derived from a pool of APP following another transport route through the biosynthetic pathway. We have observed that there is a pool of APP in hippocampal neurons that never achieves full glycosylation within the time span during which we followed the cells (M. Simons and B. De Strooper, unpublished observations). That the desialylation occurs by secreted sialidases after secretion is virtually excluded, however, because prolonged incubation of the two proteins in conditioned medium at $37^{\circ} \mathrm{C}$ did not change the relative amounts of the two forms. The function of APP processing in neurons is still not known, but we assume that $\alpha$-secretory processing of APP has an important physiological role in the central nervous system, which is in agreement with other studies (Nitsch et al., 1992).

The study of the intracellular C-terminal remnants of APP was particularly informative. Typically, the nonamyloidogenic fragments are the primary cleavage products in many cell types (Oltersdorf et al., 1990; Caporaso et al., 1992; Golde et al., 1992; Haass et al., 1992a; Lo et al., 1994). In neurons, however, we find high amounts of $\beta \mathrm{A} 4$-containing $\mathrm{C}$-terminal fragments (Fig. 6) compared with nonamyloidogenic fragments, emphasizing the possibility that neurons have an intrinsic tendency to catabolize APP in an amyloidogenic manner. Another interesting finding in this study was the identification by radiosequencing of a C-terminal APP fragment starting at $\mathrm{Asn}^{585}$ of the APP695 sequence. This fragment was detected reproducibly in all of our experiments and is an authentic product of APP processing in neurons. Because this cleavage product is found in equal amounts 


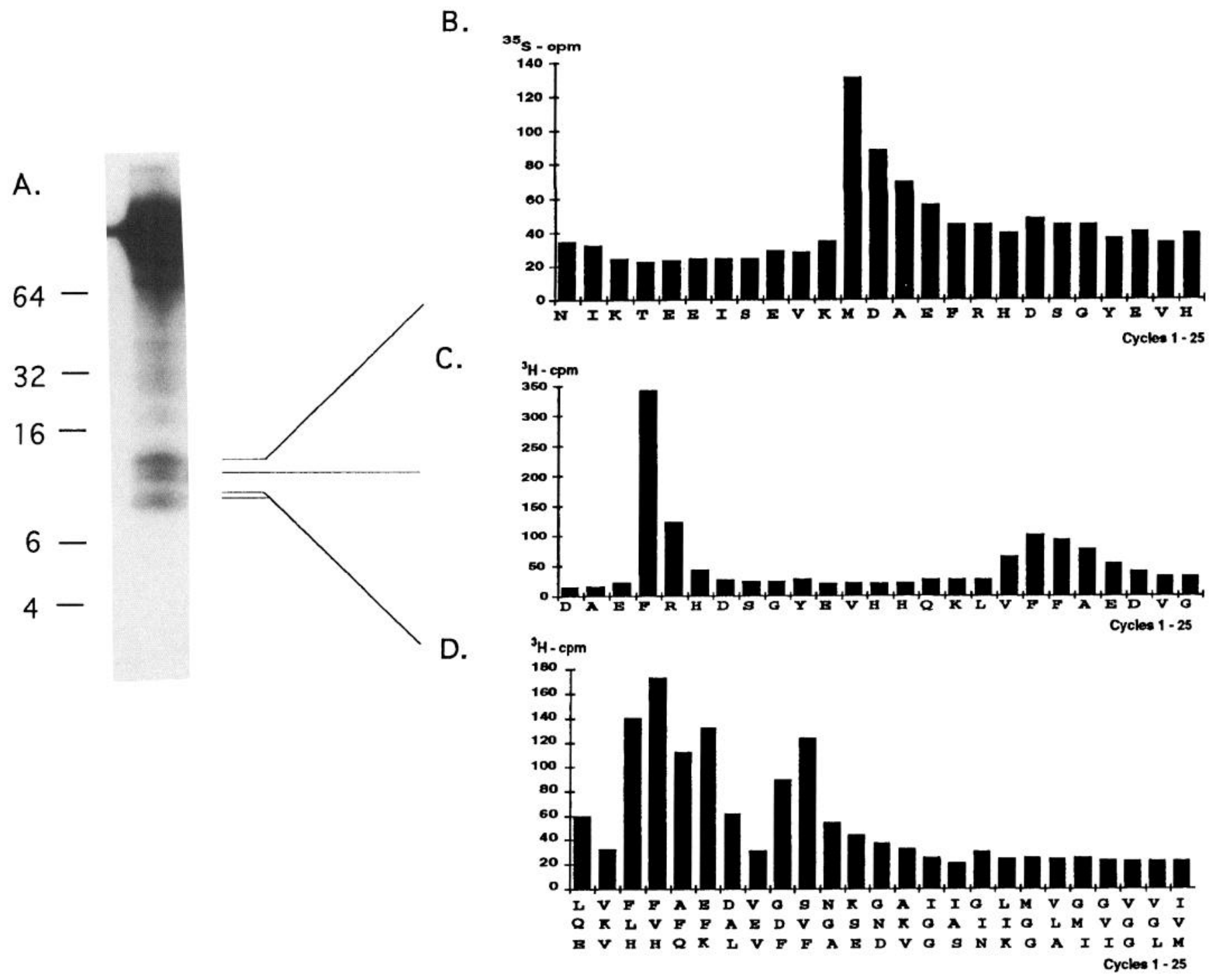

Figure 6. Analysis of APP695-derived C-terminal fragments in hippocampal neurons. A, Hippocampal neurons were infected with SFV/APP695 and metabolically labeled with $\left[{ }^{35} \mathrm{~S}\right]$ methionine or $\left[{ }^{3} \mathrm{H}\right]$ phenylalanine. Cells were solubilized, and detergent-soluble lysates were immunoprecipitated with Ab B12/4. Immunoprecipitates were separated on a 10-20\% Tris-tricine gel. Radiosequence analysis of the $\left.{ }^{35} \mathrm{~S}\right]$ methionine-labeled sample is shown for the $12 \mathrm{kDa}$ fragment $(B)$. Radioactivity obtained at each cycle for the $\left[{ }^{3} \mathrm{H}\right]$ phenylalanine-labeled samples is graphed for the $10 \mathrm{kDa}(C)$ and $8-8.5 \mathrm{kDa}$ C-terminal fragments $(D)$.

compared with those of the the $\alpha$ - and $\beta$-cleaved fragments, it represents a significant intermediate in APP metabolism in these cells. Whether this intermediate serves as a precursor for $\beta \mathrm{A} 4$ production is under further investigation. A complex set of 8-12 $\mathrm{kDa} C$-terminal fragments also has been isolated from brain homogenates, which suggests that these fragments also are produced in vivo (Estus et al., 1992). Expression of $\beta$ A4-bearing APP C-terminal fragments has shown that these fragments have a high tendency to aggregate both in vitro (Dyrks et al., 1988) and in cells (Wolf et al., 1990). Therefore, $\beta$ A4-containing fragments may function not only as precursors for $\beta \mathrm{A} 4$, but they also could form intracellular aggregates during the pathogenesis of AD.

Although radiosequencing of the $10 \mathrm{kDa} C$-terminal fragment (Fig. $6 B$ ) showed that it was generated by a single type of $\beta$-cleavage yielding a fragment starting at $\mathrm{Asp}^{1}$ of the $\beta \mathrm{A} 4$ sequence, the $8-8.5 \mathrm{kDa}$ C-terminal fragments displayed
$\mathrm{N}$-terminal heterogeneity, yielding three major products. One fragment started at residue $\mathrm{Leu}^{17}$, which is at the classical $\alpha$-secretase site (Esch et al., 1990). The other two fragments are slightly longer, with $\mathrm{N}$ termini likely starting at positions $\mathrm{Gln}^{15}$ and Glu ${ }^{11}$ of the $\beta A 4$ sequence, suggesting that $\alpha$-secretase in neurons cleaves APP at three different positions. The alternative explanation, that $\alpha$-secretase processing in neurons is performed by a set of different enzymes, is more likely. The latter possibility was advanced recently by other investigators (Zhong et al., 1994) based on studies in fibroblasts. Multiple $\alpha$-secretases also would explain the extremely relaxed specificity of $\alpha$-secretase (Sisodia et al., 1992; Maruyama et al., 1991; De Strooper et al., 1993) and the problem of inhibiting its activity by a panel of different protease inhibitors (De Strooper et al., 1992).

Of particular relevance for $\mathrm{AD}$ is that one of the alternative $\alpha$-cleaved fragments started exactly at a position identified previ- 
ously as the first residuc of $\beta \mathrm{A} 4(11-42)$, a major component of AD plaques (Masters et al., 1985; Naslund et al., 1994). This finding, therefore, corroborates our conclusion that neurons are the primary producers of amyloidogenic peptides in $\mathrm{AD}$.

When differences in APP processing in neuronal and nonneuronal cells are considered, it is also important to compare APP trafficking in various cell types. Recent studies have shown that APP is sorted to the basolateral side in epithelial MDCK cells (Haass et al., 1994; Lo et al., 1994; De Strooper et al., 1995a), where its secretory products are released. Less $\beta A 4$ appears to be produced in MDCK cells (Haass et al., 1994) compared with hippocampal neurons. Usually, basolateral proteins are routed to the dendrites in neurons and apical proteins are transported to the axon (Craig and Banker, 1994). The reason APP does not follow this scheme is not yet known. It may be that the basolateral sorting signals in APP are inactivated by post-translational modifications in neurons. One such possible modification is phosphorylation of the basolateral signal (Mostov et al., 1992). Alternatively, the protein might interact with basolateral proteins in MDCK cells and be carried piggyback to the basolateral plasma membrane. Another possibility is that the sorting machinery in neurons and epithelial cells differs, and that this leads to different sorting behavior. Future work will have to address these important issues and pinpoint the subcellular localization of the processing events.

In conclusion, our results support the working hypothesis that the intracellular trafticking of APP is related to its metabolism, and our data emphasize the necessity to investigate the metabolism of APP in polarizcd ncurons. The finding of several new proteolytic cleavage sites in neurons supports this contention and has encouraged us to analyze the metabolism of the familial mutants of APP in detail in this system as well (De Strooper et al., 1995b). We anticipate that the current approach of expressing heterologous proteins in fully differentiated neurons using the SFV expression system will prove useful for the study of many other central nervous diseases and will be widely applicable. In addition, this system might serve as an informative in vitro model for $\mathrm{AD}$ because of the high production of $\beta \mathrm{A} 4$ and amyloidogenic APP fragments.

\section{REFERENCES}

Alliquant B, Moya KL, Bouillot C, Prochianz A (1994) Amyloid precursor protein in cortical neurons: coexistence of two pools differentially distributed in axons and dendrites and association with cytoskeleton. $\mathrm{J}$ Neurosci 14:6842-6855.

Anderson JP, Chen Y, Kim KS, Robakis NK (1992) An alternative secretase cleavage produces soluble Alzheimer's amyloid precursor protein containing a potentially amyloidogenic sequence. $\mathbf{J}$ Neurochem 59:2328-2331.

Bottenstein JE, Sato GH (1979) Growth of a rat neuroblastoma cell line in serum-free supplemented medium. Proc Natl Acad Sci USA 76:514-519.

Busciglio J, Gabuzda DH, Matsudaira P, Yankner BA (1993) Generation of beta-amyloid in the secretory pathway in neuronal and non-neuronal cells. Proc Natl Acad Sci USA 90:2092-2096.

Caporaso GL, Gandy SE, Buxbaum JD, Greengard P (1992) Chloroquine inhibits intracellular degradation but not secretion of Alzheimer beta/A4 amyloid precursor protein. Proc Natl Acad Sci USA $89: 2252-2256$.

Cork LC, Masters C, Beyreuther K, Price DL (1990) Development of senile plaques: relationships of neuronal abnormalities and amyloid deposits. Am J Pathol 137:1383-1392.

Craig AM, Banker GA (1994) Neuronal polarity. Annu Rev Neurosci $17: 267-310$.

Cras P, Kawai M, Lowery D, Gonzalez DeWhitt P, Greenberg B, Perry G (1991) Senile plaque neurites in Alzhcimer's disease accumulate amyloid precursor protein. Proc Natl Acad Sci USA 88:7552-7556.
De Hoop MJ, Huber LA, Stenmark H, Williamson E, Zerial M, Parton RG, Dotti CG (1994) The involvement of the small GIP-binding protein Rab5a in neuronal endocytosis. Neuron 13:11-22.

De Strooper B, Craessaerts K, Dewachter I, Moechars D, Greenberg B, Van Leuven F, Van Den Berghe H (1995a) Basolateral secretion of amyloid precursor protein in MDCK cells is disturbed by alterations of intracellular $\mathrm{pH}$ and by introducing a mutation associated with familial Alzheimer's disease. J Biol Chem 270:4058-4065.

De Strooper B, Simons M, Multhaup G, Van Leuven F, Beyreuther K, Dolti CG (1995b) Production of intracellular amyloid-containing fragments in neurons expressing mutants of human amyloid precursor protein causing Alzheimer's disease and protection against amyloidogenesis by subtle amino acid substitutions in the rodent sequence. EMBO J 14:4932-4938.

De Strooper B, Umans L, Van Leuven F, Van Den Berghe H (1993) Study of the synthesis and secretion of normal and artificial mutants of murine amyloid precursor protein (APP): cleavage of APP occurs in a late compartment of the default secretion pathway. J Cell Biol 121:295-304.

De Strooper B, Van Leuven F, Van den Berghe H (1992) $\alpha 2$ Macroglobulin and other proteinase inhibitors do not interfere with the secretion of amyloid precursor protein in mouse neuroblastoma cells. FEBS Lett 308:50-53.

Dotti CG, Sullivan CA, Banker GA (1988) The establishment of polarity by hippocampal neurons in culture. J Neurosci 8:1454-1468.

Dyrks T, Weidemann A, Multhaup G, Salbaum JM, Lemaire HG, Kang J, Muller HB, Masters CL, Beyreuther K (1988) Identification, transmembrane orientation and biogenesis of the amyloid A4 precursor of Alzheimer's disease. EMBO J 7:949-957.

Esch FS, Keim PS, Beattie EC, Blacher RW, Culwell AR, Oltersdorf T, McClure D, Ward PJ (1990) Cleavage of amyloid beta peptide during constitutive processing of its precursor. Science 248:1122-1124.

Estus S, Golde TE, Kunishita T, Blades D, Lowery D, Eisen M, Usiak M, Qu XM, Tabira T, Greenberg BD, Younkin SG (1992) Potentially amyloidogenic, carboxyl-terminal derivatives of the amyloid protein precursor. Science 255:726-728.

Games D, Adams D, Alessandrini R, Rarbour R, Rerthelette P, Rlackwell C, Carr T, Clemens J, Donaldson T, Gillespie F, Guido T, Hagopian S, Johnson-Wood K, Khan K, Lee M, Leibovitz P, Lieberburg I, Little S, Masliah E, McConlogue L, Montoya-Zavala M, Mucke L, Paganini L, Penniman E, Power M, Schenk D, Seubert P, Snyder B, Soriano F, Tan H, Vitalc J, Wadsworth S, Wolozin B, Zhao J (1995) Alzheimer-type neuropathology in transgenic mice overexpressing $V 717 \mathrm{~F}$ beta-amyloid precursor protein. Nature 373:523-527.

Glenner G, Wong C (1984) Alzheimer's disease: initial report of the purification and characterization of a novel cercbrovascular amyloid protein. Biochem Biophys Res Commun 120:885-890.

Golde TE, Estus S, Younkin LH, Selkoe DJ, Younkin SG (1992) Processing of the amyloid protein precursor to potentially amyloidogenic derivatives. Science 255:728-730.

Goslin K, Banker G (1991) Rat hippocampal neurons in low-density culture. In: Culturing nerve cells (Banker G, Goslin K, eds), pp 251-281. Cambridge: MIT.

Haass C, Hung AY, Selkoe DJ (1991) Processing of $\beta$-amyloid precursor protein in microglia and astrocytes favors an internal localization over constitutive secretion. J Neurosci 11:3783-3793.

Haass C, Koo EH, Mellon A, Hung AY, Selkoe DJ (1992a) Targeting of cell-surface beta-amyloid precursor protein to lysosomes: alternative processing into amyloid-bearing fragments. Nature 357:500-503.

Haass C, Koo EH, Teplow DB, Selkoc DJ (1994) Polarized secretion of beta-amyloid precursor protein and amyloid beta-peptide in MDCK cells. Proc Natl Acad Sci USA 91:1564-1568.

Haass C, Schlossmacher MG, Hung AY, Vigo Pelfrey C, Mellon A, Ostaszewski BL, Lieberburg I, Koo EH, Schenk D, Teplow DB, Selkoe DJ (1992b) Amyloid beta-peptide is produced by cultured cells during normal metabolism. Nature 359:322-325.

Hilbich C, Monning U, Grund C, Masters CL, Beyreuther K (1993) Amyloid-like properties of peptides flanking the epitope of amyloid precursor protein-specific monoclonal antibody $22 \mathrm{C} 11$. J Biol Chem 268:26571-26577.

Hung AY, Koo EH, Haass C, Selkoe DJ (1992) Increased expression of beta-amyloid precursor protein during neuronal differentiation is not accompanied by secretory cleavage. Proc Natl Acad Sci USA 89:9439-9443. 
Hyman BT, Van Hoesen GW, Damasio AR (1990) Memory-related neural systems in Alzheimer's disease: an anatomic study. Neurology 4): 1721-1730.

Ikonen E, Parton RG, Hunziker W, Simons K, Dotti CG (1993) Transcytosis of the polymeric immunoglobulin receptor in cultured hippocampal neurons. Curr Biol 3:635-644.

Kang J, Lemaire HG, Unterbeck A, Salbaum JM, Masters CL, Grzeschik KH, Multhaup G, Beyreuther K, Muller HB (1987) The precursor of Alzheimer's disease amyloid A4 protein resembles a cell-surface receptor. Nature 325:733-736.

Kim KS, Miller DL, Spienza VJ, Chen C-MJ, Bai C, Grundke-Iqbal I, Currie JR, Wiesniewski HM (1988) Production and characterisation of Inomoclonal antibodies reactive to synthetic cerebrovascular amyloid peptide. Neurosci Res Commun 2:121-130.

Koo EH, Squazzo SL (1994) Evidence that production and relcase of amyloid beta-protein involves the endocytic pathway. J Biol Chem 269:17386-17389.

Liljestrom P, Garoff H (1991) A new generation of animal cell expression vectors based on the Semliki forest virus replication. Biotechnol $9: 1356-1361$

Lo AC, Haass C, Wagner SL, Teplow DB, Sisodia SS (1994) Metabolism of the "Swedish" amyloid precursor protein variant in Madin-Darby canine kidney cells. J Biol Chem 269:30966-30973.

Lowery DE, Pasternack JM, Gonzalez DeWhitt PA, Zurcher Neely H, Tomich CC, Altman RA, Fairbanks MB, Heinrikson RL, Younkin SG, Greenberg BD (1991) Alzheimer amyloid precursor protein produced by recumbinant baculovirus expression: proteolytic processing and protease inhibitory properties. J Biol Chem 266:19842-19850.

Maruyama K, Kametani F, Usami M, Yamao Harigaya W, Tanaka K (1991) "Secretase," Alzheimer amyloid protein precursor-secreting enzyme is not sequence-specific. Biochem Biophys Res Commun $179: 1670-1676$.

Masters C., Simms G, Weinman N, Multhaup G, McDonald B, Beyreuther $\mathrm{K}$ (1985) Amyloid plaque core protein in Alzheimer's disease and Down's syndrome. Proc Natl Acad Sci USA 82:4245-4249.

Mostov K, Apodaca G, Aroeti B, Okamato C (1992) Plasma membrane protein sorting in polarized epithelial cells. J Cell Biol 1 16:577-583.

Mullan M, Crawford F (1993) Genetic and molecular advances in Alzheimer's disease. Trends Neurosci 16:398-403.

Naslund J, Schiernhorn A, Hellmann U, Lannfelt L, Roses AD, Tuernberg LO, Silberring J, Gandy SE, Winblad B, Greengard P, Nordstedt
C, Terenius L (1994) Relative abundance of Alzheimer $A \beta$ amyloid peptide variants in Alzheimer's disease and normal aging. Proc Natl Acad Sci USA 91:8378-8382.

Nitsch RM, Slack BE, Wurtman RJ, Growdon JH (I992) Release of Alzheimer amyloid precursor derivatives stimulated by activation of muscarinic acetylcholine receptors. Science 258:304-307.

Olkkonen VM, Liljestrom P, Garoff H, Simons K, Dotti CG (1993) Expression of heterologous proteins in cultured rat hippocampal neurons using the Semliki Forest virus vector. J Neurosci Res 35:445-451.

Oltersdorf T, Ward PJ, Henriksson T, Beattie EC, Neve R, Lieberburg I, Fritz LC (1990) The Alzheimer amyloid precursor protein: identification of a stable intermediate in the biosynthetic/degradative pathway. $J$ Biol Chem 265:4492-4497.

Peng I, Binder L, Black M (1986) Biochemical and immunological analyses of cytoskeletal domains in neurons. J Cell Biol 102:252-262.

Robertson EJ (1987) Teratocarcinomas and embryonic stem cells, a practical approach. Oxford: IRL.

Selkoe DJ (1994) Alzheimer's disease: a central role for amyloid. J Neuropathol Exp Neurol 53:438-447.

Simons M, Ikonen E, Tienari PJ, Cid-Arregui A, Monning U, Beyreuther K, Dotti CG (1995) Intracellular routing of human amyloid protein precursor: axonal delivery followed by transport to the dendrites. J Neurosci Res 41:121-128.

Sisodia SS (1992) Beta-amyloid precursor protein cleavage by a membrane-bound protease. Proc Natl Acad Sci USA 89:6075-6079.

Sisodia SS, Koo EH, Beyreuther K, Unterbeck A, Price DL (1990) Evidence that beta-amyloid protein in Alzheimer's discase is not derived by normal processing. Science 248:492-495.

Weidemann A, Konig G, Bunke D, Fischer P, Salbaum JM, Masters CL, Beyreuther K (1989) Identification, biogenesis, and localization of precursors of Alzheimer's disease A4 amyloid protein. Cell $57: 115-126$.

Wolf D, Quon D, Wang Y, Cordell B (1990) Identification and characterization of C-terminal fragments of the beta-amyloid precursor produced in cell culture. EMBO J 9:2079-2084.

Yamazaki T, Selkoe DJ, Koo EH (1995) Trafficking of cell surface betaamyloid precursor protein: retrograde and transcytotic transport in cultured neurons. J Cell Biol 129:431-442.

Zhong Z, Higaki J, Murakami K, Wang Y, Catalano R, Quon D, Cordell B (1994) Secretion of beta-amyloid precursor protein involves multiple cleavage sites. J Biol Chem 269:627-632. 